\title{
Odwrót od wolnego handlu na przykładzie Partnerstwa Transpacyficznego
}

\begin{abstract}
Streszczenie: W ostatnich paru latach do władzy doszły w niektórych państwach zachodnich partie prawicowe, które bardziej posługują się argumentami politycznymi i nie dostrzegają korzyści, jakie niesie ze sobą wolny handel. Przykładem może być Parnterstwo Transpacyficzne (TPP), które miało doprowadzić do przyśpieszenia handlu i wzmocnienia współpracy gospodarczej w regionie Azji i Pacyfiku. Partnerstwo to miało też być przeciwwagą dla ekspansji gospodarczej Chin w tym regionie. Stany Zjednoczone wspierały prawie 7-letni proces negocjacji i doprowadziły przy końcu 2015 roku do podpisania porozumienia o utworzeniu TPP. Do początku 2017 roku porozumienie to nie zostało jednak ratyfikowane przez parlamenty państw członkowskich, a w lutym 2017 roku prezydent Donald Trump wycofał USA z tego partnerstwa. Stworzyło to szansę dla Chin, które forsują swoją koncepcję Regionalnego Kompleksowego Partnerstwa Gospodarczego (RCEP) i osłabiło zaufanie do Stanów Zjednoczonych wśród wielu dotychczasowych sojuszników tego mocarstwa.
\end{abstract}

Słowa kluczowe: wolny handel, protekcjonizm, TPP, USA, Chiny, Region Pacyfiku, RCEP

\section{Wprowadzenie}

$\mathbf{W}$ ostatnich latach na skutek różnych wydarzeń w gospodarce światowej oraz przejęcia władzy w niektórych krajach przez partie prawicowo-nacjonalistyczne przewagę zyskują w wielostronnych negocjacjach handlowych takich jak TPP (Trans-Pacific Partnership $=$ Partnerstwa Transpacyficznego) przesłanki polityczne nad korzyściami ekonomicznymi. Mówiąc inaczej, nie tylko w negocjacjach handlowych nieuwzględniane są argumenty ekonomistów, ale górę biorą różne uprzedzenia i obawy polityków, zainteresowanych nie tyle korzyściami, jakie można uzyskiwać z wolnego handlu, ile przede wszystkim utrzymaniem się jak najdłużej u władzy. A to oznacza konieczność obrony różnie pojmowanych interesów narodowych. Niektórym politykom wydaje się, że tylko w ten sposób można pozyskać znaczną część elektoratu do swojej idei quasi wolnego czy też sprawiedliwego (fair trade) handlu międzynarodowego.

Podstawowym argumentem ekonomistów przemawiającym za wolnym od interwencji państw handlem jest sformułowana na początku XIX wieku przez angielskiego ekonomistę Davida Ricardo teoria przewagi komparatywnej (kosztów komparatywnych). W świetle tej teorii wzrost handlu międzynarodowego jest korzystny dla wszystkich stron. Sa jednak wygrani, którzy tworzą nowe specjalizacje produkcji i dużo eksportują, jak i przegrani. Minione dwa stulecia rozwoju handlu międzynarodowego potwierdziły ogólną prawidłowość, że zasada przewagi komparatywnej, która jest podstawą wszystkich międzynarodowych umów handlowych, zakłada, że państwom opłaca się specjalizować w tych obszarach, w których mają przewagę. To może być tania siła robocza, warunki klimatyczne lub ekonomia skali. Przewaga komparatywna może być tworzona, 
np. koreański przemysł stoczniowy, który zniszczył polskie stocznie (i potężne stocznie japońskie), powstał w kraju, który wcześniej zajmował się niemal wyłącznie uprawą ryżu. Stało się tak, bo przewaga komparatywna zakłada swobodną i uczciwą konkurencję między uczestnikami rynku, brak sztucznych barier i swobodny przepływ technologii.

Do połowy lat 1990-tych, kiedy postępowała stopniowa liberalizacja handlu międzynarodowego i podpisana została pod auspicjami WTO (Światowej Organizacji Handlu) globalna umowa handlowa, można było zaobserwować swoiste wycofywanie się państw z ograniczenia handlu towarami i nieco później także usługami poprzez znoszenie ceł i zmniejszanie różnych restrykcji pozataryfowych (Strange, 1996; Kobrin, 2005). Niestety w latach następnych negocjacje WTO były bezskuteczne. Kraje gospodarczo wysoko rozwinięte nie potrafiły porozumieć się w kwestii dalszej liberalizacji handlu międzynarodowego z krajami rozwijającymi się. Pewien przełom nastąpił dopiero po podpisaniu 7 grudnia 2013 roku tzw. pakietu z Bali. Negocjacje te zakończyły się sukcesem, bo przedstawiciele obu tych grup krajów postanowili nie zajmować się najbardziej drażliwymi kwestiami (własności intelektualnej czy handlu usługami), a skoncentrować się na sposobach ułatwienia wymiany towarowej. Kraje zachodnie zgodziły się także by kraje rozwijające się mogły inwestować budżetowe pieniądze w podstawowe branże własnego przemysłu rolniczego, by zagwarantować sobie bezpieczeństwo żywnościowe (ale już problem dotowania rolnictwa w bogatych krajach Zachodu ze szkodą dla biedniejszych został wtedy wstydliwie przemilczany). Do tego czasu kraje zachodnie chciały, kosztem słabszych krajów rozwijających się, rozszerzyć prawa do własności intelektualnej oraz mocnej chronić własne inwestycje. To nie miało nic wspólnego z korzystną dla wszystkich przewagą komparatywna, za to wiele z ochroną interesów wielkich korporacji. Pakiet z Bali podpisano, bo podczas rozmów skupiono się na ułatwieniach, jakie daje zniesienie barier handlowych, a nie na wzmacnianiu potęgi takich koncernów, jak Monsanto lub Microsoft (Habisch, 2013; Cohn, 2011). Późniejsze negocjacje handlowe WTO w Hong-Kongu i Dausze nie doprowadziły do oczekiwanego, pełnego uwolnienia handlu od polityki państw narodowych. Nie tylko WTO, lecz także wszystkie inne organizacje międzynarodowe i instytucje w poszczególnych państwach, które sprzyjały rozwojowi handlu stały się w ostatnich latach coraz słabsze (Yough, 2007; Mildner, 2009). Stąd inicjatywa Stanów Zjednoczonych skierowana na „uporządkowanie” handlu towarami i usługami z wybraną grupa krajów i utworzenia Partnerstwa Transpacyficznego, a w odniesieniu do krajów Unii Europejskiej próba zawarcia porozumienia TTIP (Transatlantic Trade and Investment Partnership - Transatlantyckiego Partnerstwa w dziedzinie Handlu i Inwestycji).

\section{Kontrowersyjne Partnerstwo Transpacyficzne}

Jednym z głównych motywów administracji prezydenta Baracka Obamy do podjęcia w 2012 roku negocjacji z 11 krajami w sprawie utworzenia Partnerstwa Transpacyficznego było zarówno utworzenie nowego bloku handlowego, jako przeciwwagi dla ekspansji gospodarczej i politycznej Chin w regionie Azji i Pacyfiku, jak równie dążenie do utrzymania w USA wzrostu gospodarczego na odpowiednio wysokim poziomie i obniżenie bezrobocia. Partnerstwo to miało połączyć 12 państw na czterech kontynentach, 
których gospodarki są łącznie warte ok. 28 bln dol. (87 bln zł): USA, Kanadę, Australię, Brunei, Chile, Japonię, Malezję, Meksyk, Nową Zelandię, Peru, Singapur i Wietnam. Wspomniane 12 krajów TPP wytwarza 40 proc. światowego PKB. Drugim powodem było to, że region Azji i Pacyfiku to bardzo ważny rynek zbytu na produkty wytwarzane w USA. Jak potwierdzają to dane z tabeli 1, wartość amerykańskiego eksportu do krajów TPP prawie trzykrotnie przewyższyła w 2012 roku wartość eksportu towarów z USA do wszystkich krajów Unii Europejskiej.

Negocjacje nad utworzeniem TPP trwały pięć lat i toczyły się w różnych miastach, m.in. w Ho Chi Minh, Kuala Lumpur, Limie, Melbourne, San Diego oraz w innych krajach regionu Pacyfiku, gdzie omawiano różne szczegóły związane z taryfami celnymi na wszystko, od mięsa po części samochodowe. Cechą wspólną tych negocjacji, podobnie zresztą jak niezakończonych jeszcze negocjacji w sprawie utworzenia TTIP było to, że odbywały się one w tajemnicy, bez udziału społeczeństwa i parlamentów narodowych, za to z dużym zaangażowaniem korporacyjnym lobbystów. Jednak negocjacje w sprawie utworzenia TPP nie spotkały się z taką krytyką jak negocjacje dotyczące porozumienia handlowego USA-Europa (TTIP). Wynikało to, być może, z mniejszego zainteresowania mediów regionem Azji i Pacyfiku oraz także z mniejszego zagrożenia, jakie TPP stworzyłoby dla Europy i całej gospodarki światowej.

Ogromne różnice w poziomie rozwoju gospodarczego krajów sygnatariuszy TPP sprawiły, że trudno było uzgodnić wiele podstawowych kwestii. Okazało się, że kraje o wysokim PKB per capita, takie jak np. Singapur (62 tys. dol.) mają inne cele i oczekiwania związane z udziałem w tym partnerstwie niż ,biedny” Wietnam, gdzie ten wskaźnik jest 30-krotnie niższy. W tym ostatnim kraju większość społeczeństwa nadal utrzymuje się z rolnictwa, w tym z uprawy ryżu.

Trudno więc było wynegocjować odpowiednie stawki celne na ryż oraz mleko, a także na samochody i nowe technologie. Takim krajom jak Wietnamowi, Malezji i Japonii zależało na utrzymaniu wysokich taryf celnych, aby chronić rodzimych rolników. Z kolei amerykańscy producenci samochodów obawiali się konkurencji ze strony japońskich potentatów motoryzacyjnych. Toyota już sprzedaje więcej samochodów niż jakikolwiek inny producent na świecie. USA zabiegały również o zapisy dotyczące wprowadzenia jednolitych, wysokich standardów pracy, umożliwienia działalności związkom zawodowym w takich krajach jak Wietnam oraz przede wszystkim wprowadzenie odpowiednich regulacji chroniących własność intelektualną, aby zapobiec kradzieży technologii. Faktem bowiem jest, że Stany Zjednoczone są najbardziej innowacyjnym krajem na świecie i nie może dziwić to, że od tego partnerstwa także oczekują najwyższego poziomu ochrony ich własności intelektualnej. W trakcie negocjacji nie zbadano jednak wpływu TPP na rozwój handlu światowego. Trudno też było oszacować zyski amerykańskich i australijskich eksporterów wołowiny do Japonii po tym, jak stawki celne na ten produkt w tym kraju zostaną zmniejszone z 38,5\% do 9\%, ale dopiero na przestrzeni 15 lat (Bajekal, 2015).

Porozumienie o zawarciu tego Partnerstwa ogłoszono 5 października 2015 roku. Jednak to największe, regionalne porozumienie handlowe miało wejść w życie dopiero wtedy, gdy zostanie ratyfikowane przez wszystkie 12 państw-stron tego porozumienia. Nie doszło do tego do początku 2017 roku, jednak już w 2015 roku znacznie zwiększyła się wymiana handlowa USA z pozostałymi krajami TPP. Udział tych krajów w globalnym 
Wykres 1. Handel towarami Stanów Zjednoczonych z wybranymi krajami w mld dol.

Import towarów do USA w 2012 roku

w mld. dol.

$$
\begin{array}{r}
\text { UE } \\
\text { Kraje TPP }
\end{array}
$$

Chiny

Kanada

Meksyk

Japonia

Niemcy

Korea Południowa

Arabia Saudyjska

Wielka Brytania

Francja

Indie

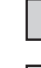<smiles>C1CCCCC1</smiles>

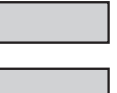

58,9

55,67

146,39

$\mathbf{2 7 7 , 5 7}$

381,65

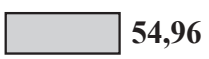

\section{5,58}

323,94

zmiana $\mathrm{w} \%$

w stosunku

do 2011 roku

843,19

$+5,6$

$$
+6,6
$$

$+2,7$

$+5,6$

$+13,5$

$+10,2$

$+2,9$

$+17,3$

$+7,2$

$+4,2$

$+12,1$

Eksport towarów z USA w 2012 roku w mld dol. w mld. dol.

zmiana $\mathrm{w} \%$

w stosunku

do 2011 roku

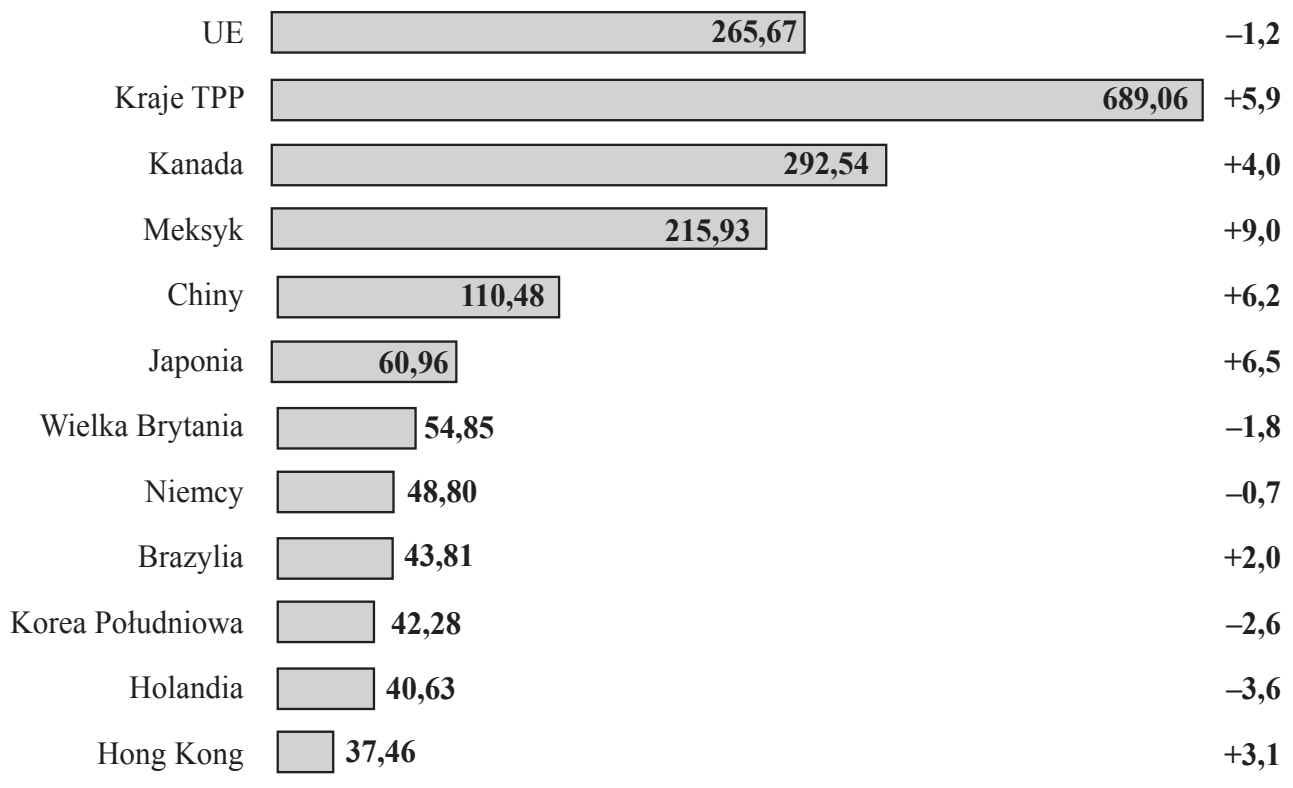

Źródło: The US Department of Commerce, „The Wall Street Journal” 25.11.2013, s. 8. 
handlu USA wyniósł w tym roku aż 39 proc. Po ratyfikacji tej umowy udział ten z pewnością byłby większy. Umowa TPP przewiduje, że jeśli nie dojdzie do jej ratyfikacji w ciągu najbliższych dwóch lat tj. do 2018 roku, to umowa ta może wejść w życie po jej ratyfikacji przez co najmniej sześć państw wytwarzających $85 \%$ PKB. Warto przypomnieć, że same Stany Zjednoczone wytwarzają ok. 60\% PKB i dlatego bez ratyfikacji tego układu przez amerykański Kongres TPP pozostanie tylko projektem na papierze i nigdy nie wejdzie w życie.

Za prezydentury Baracka Obamy, który dokonał znaczącej zmiany swojej polityki zagranicznej i postawił na zacieśnienie współpracy gospodarczo-politycznej i wojskowej z sojuszniczymi krajami Azji (Pivot to Asia) nic jednak nie zapowiadało, że przewagę uzyskają motywy polityczne nad korzyściami gospodarczymi. Te ostatnie odniosłyby z tego układu przede wszystkim gospodarki państw bogatych czyli USA, Kanady, Japonii i Australii. Największa, polityczną korzyścią dla Stanów Zjednoczonych mogłoby być to, że od początku negocjacji zamierzano użyć TPP jako swoistego instrumentu nacisku na drugą największą na świecie gospodarkę, tj. na Chiny.

Zakładano także, że Chiny jako największy, światowy eksporter towarów stanie się albo przeciwnikiem TPP, albo też kandydatem do przyszłego członkowstwa w tym regionalnym porozumieniu handlowym. Ministerstwo Spraw Zagranicznych Państwa Środka przedstawiło pismo ugodowe, według którego „Chiny żywią nadzieję, że zarówno to porozumienie, jak i inne układy związane $\mathrm{z}$ wolnym handlem są w stanie przynosić obopólne korzyści” (Panda, 2015). Wprawdzie administracja prezydenta Baracka Obamy sygnalizowała, że może rozważyć członkostwo Chin w TPP, jednak od razu zastrzegła, że zajmie to lata negocjacji. $Z$ drugiej strony prezydent Barack Obama wielokrotnie mówił o tym, że nie można pozwolić takim państwom jak Chiny, aby ,pisały one zasady, w oparciu o które ma funkcjonować gospodarka globalna" (Bajekal, 2015; The Transpacific..., 2015). Niektórzy przedstawiciele administracji w Waszyngtonie utrzymywali, że utworzenie TPP nie jest skierowane przeciwko interesom jakiegokolwiek kraju i ma na celu głównie ,podwyższenie standardów obowiązujących w istniejącym systemie handlu międzynarodowego" (Blumenstein, 2013). Partnerstwo Transpacyficzne miało też być „otwarte” na przyjęcie innych krajów, o ile byłyby one w stanie spełnić wszelkie wymogi związane z członkostwem w tym regionalnym bloku handlowym. Wydarzenia z przełomu 2016 i 2017 roku pokazały jednak, że nie tylko nie doszło do rozszerzenia tego bloku handlowego o nowe kraje członkowskie, lecz prezydent Donald Trump podjął niezrozumiałą i szokującą dla pozostałych uczestników tego porozumienia decyzję o wycofaniu się Stanów Zjednoczonych z TPP i w to miejsce zawarcia bilateralnych umów handlowych, korzystnych oczywiście dla USA, a nie dla poszczególnych krajów Azji i Pacyfiku.

\section{Odwrót od "wolnego" handlu}

W praktyce może to oznaczać odwrót tego supermocarstwa od globalizacji, którą do niedawna Stany Zjednoczone najbardziej wspierały i powrót do polityki protekcjonizmu. Należy zaznaczyć, że odwrót od globalizacji jest do pewnego stopnia zjawiskiem naturalnym. Wiele bowiem danych statystycznych potwierdza, że klasa 
średnia krajów rozwiniętych, czyli najważniejsza grupa wyborców, na procesach globalizacyjnych straciła. Do niedawna wśród czołowych ekonomistów panowała niemal powszechna zgoda co do tego, że wolny handel i globalizacja są korzystne dla wszystkich stron. Jednak od paru lat pojawiają się coraz liczniejsze wątpliwości - nie co do samych korzyści brutto, ale co do ich dystrybucji między różne grupy społeczne. W badaniu w 2016 roku grupa ekonomistów z MIT i kilku innych uczelni oszacowała, że ze względu na konkurencję importu z Chin do USA zniknęły ponad dwa miliony miejsc pracy (Vanishing, 2016). Należy przypomnieć, że na podobne, choć nie zawsze poparte odpowiednimi (wiarygodnymi) danymi statystycznymi zagrożenie dla amerykańskiej gospodarki i ludzi pracy wskazywali w trakcie swojej kampanii prezydenckiej zarówno Donald Trump jak i Hillary Clinton (Roberts, Felton, 2016; Bremmer, 2017). W praktyce jednak nie wszystkie miejsca pracy, jakie znikają w USA, przenoszone są bezpośrednio do Chin, a przynajmniej nie w takich rozmiarach, jak to sugerują niektórzy amerykańscy politycy i media. Według badań ekspertów z McKinsey Global Institute Stany Zjednoczone straciły w latach 2000-2010 ok. 700 tys. ogólnej liczby 6 milionów miejsc pracy w sektorze produkcji przemysłowej. $Z$ tego tylko jedna trzecia została przeniesiona do Chin, głównie do przemysłu tekstylnego i elektronicznego. Pozostała część miejsc pracy została utracona w wyniku dużego spadku popytu na rynku amerykańskim, będącego efektem recesji gospodarczej z 2008 roku (Foroohan, 2016).

\section{Wykres 2. Import do USA z Chin jako \% PKB}

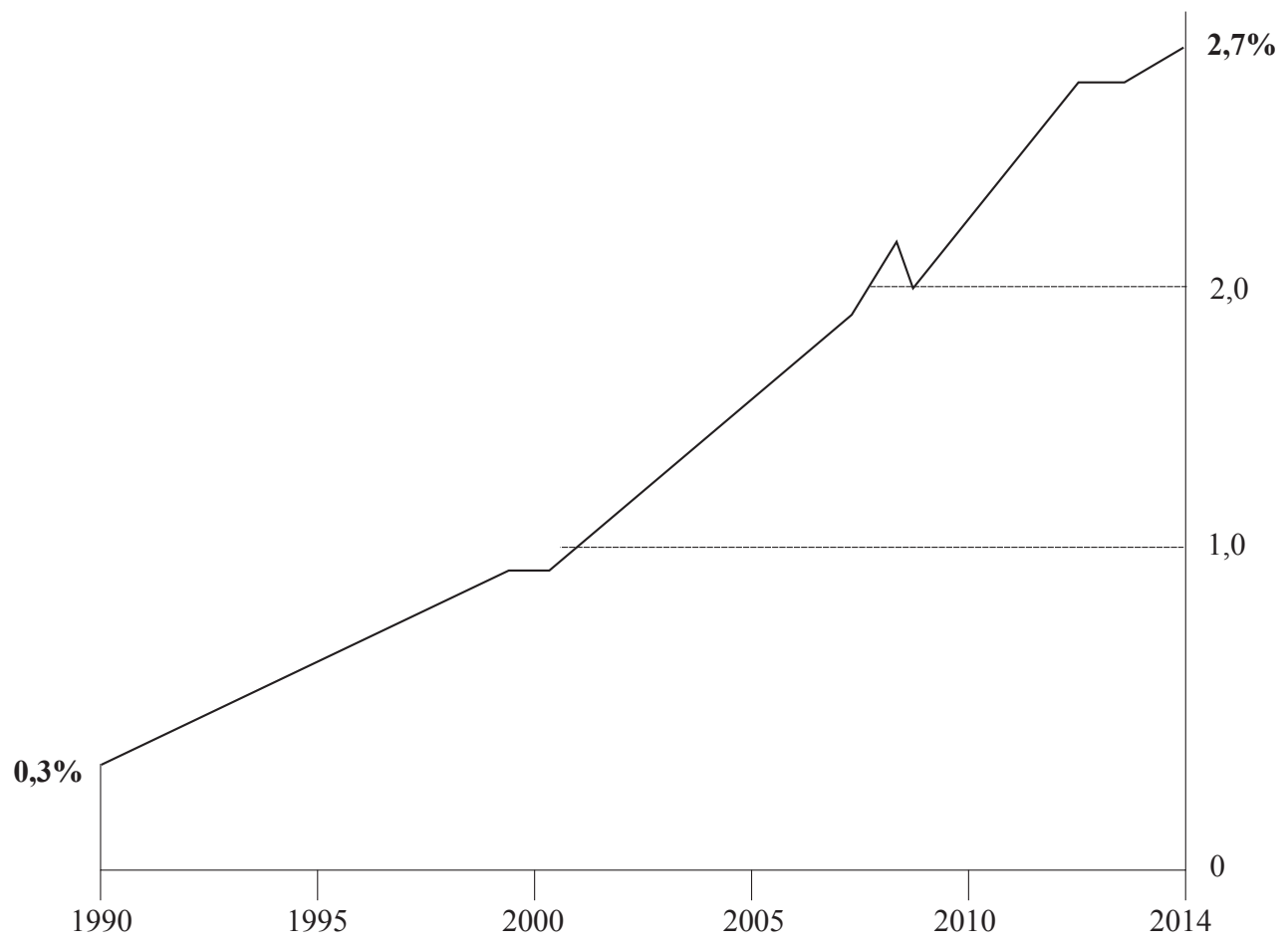

Źródło: „Times” 11.04.2016, s. 40. 


\section{Wykres 3. Zatrudnienie w amerykańskim sektorze produkcji jako \% ogólnego zatrudnienia}

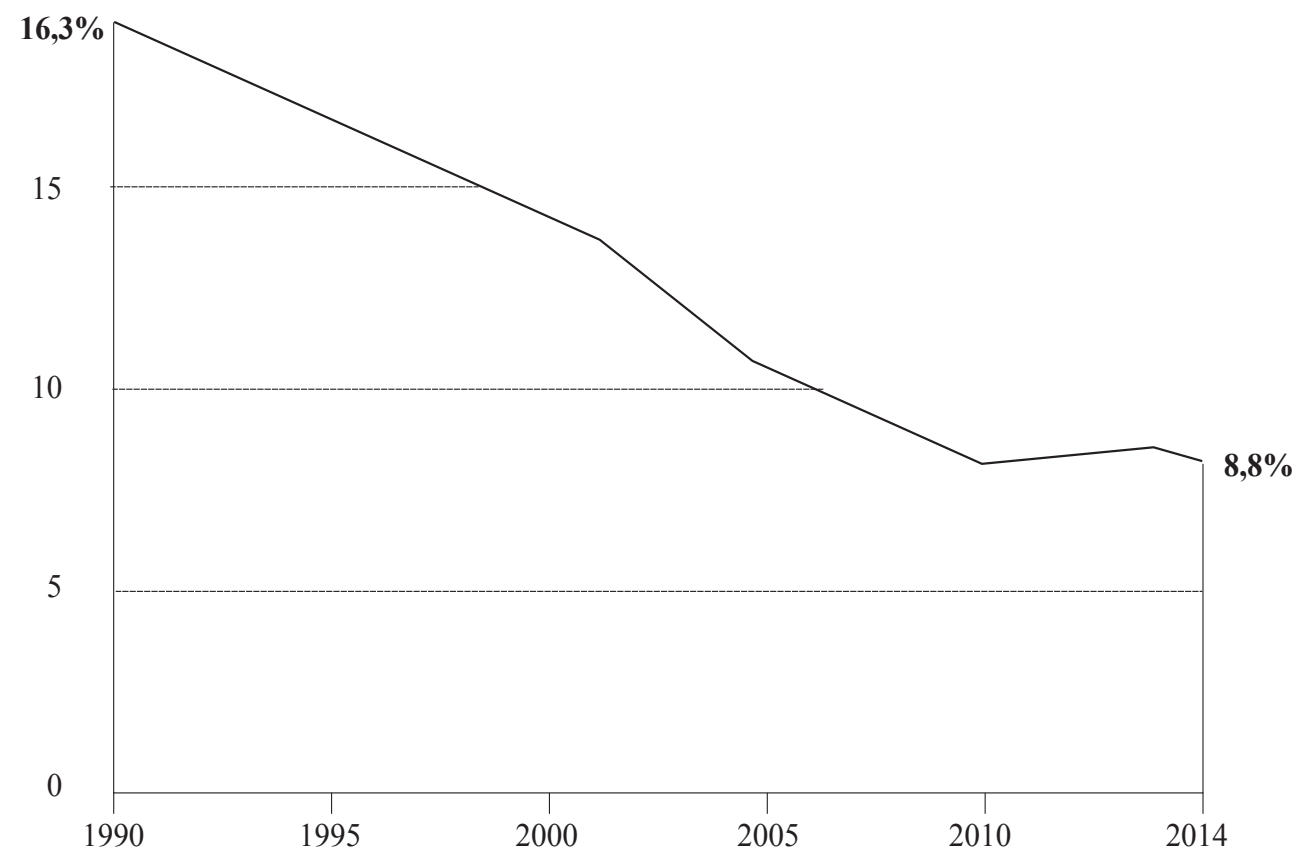

Źródło: Jak w wykresie 2.

Spadek popytu, podobnie jak ucieczka miejsc pracy do Chin, nie były jednak jedynymi przyczynami zmniejszenia się w USA liczby miejsc pracy. Poważniejszą przyczyną była, jest i będzie postępująca czwarta rewolucja technologiczna i związana z tym procesem automatyzacja procesu produkcji i zastępowanie w wielu branżach pracy żywej robotami. Szczególnie jest to odczuwalne właśnie w Stanach Zjednoczonych i Japonii oraz pozostałych krajach wysoko rozwiniętych, gdzie w erze komputerów przyszedł czas na automatyzację, robotyzację i sztuczną inteligencję. W wyniku tych procesów na rynku pracy, nie tylko w USA, dojdzie w najbliższych latach do ogromnych zmian i nikt nie będzie mógł się czuć bezpiecznie, gdyż - jak prognozują to naukowcy z Uniwersytetu w Oksfordzie (Davis, Blass, 2007; Eberstadt, 2016) - w ciągu najbliższych 20-30 lat połowa miejsc pracy zostanie przejęta przez roboty. Przejmą one już nie tylko większość prac manualnych, lecz dzięki rozwojowi nowych technologii będą w stanie wykonywać dużo trudniejsze zadania.

Współcześni politycy, nie tylko amerykańscy, zdają się jednak nie dostrzegać oczywistych zależności między „kurczeniem się” miejsc pracy i postępem technologicznym, jak również między zmniejszaniem się liczby głównie nisko płatnych miejsc pracy przy jednoczesnym pojawianiu się wysoko płatnych miejsc pracy w wielu krajach od Danii po Singapur wykorzystujących wolny handel i swobodny przepływ kapitałów dla podniesienia konkurencyjności swoich gospodarek. Trudno jednoznacznie rozstrzygnąć kto ponosi większą czy mniejszą winę za ten brak zrozumienia korzyści wynikających z wolnego handlu. Z pewnością dużą winę za to ponoszą ekonomiści, politolodzy 
i przedstawiciele innych nauk społecznych, którym nie udało się w przekonywujący sposób wytłumaczyć opinii publicznej oraz nie zawsze przecież odpowiednio wykształconym i posiadającym szeroką wiedzę politykom, dlaczego wolny handel służy zarówno Stanom Zjednoczonym, jak i pozostałym krajom uczestniczącym w międzynarodowej wymianie towarów i usług. Pewną winę za ten stan rzeczy ponoszą także media, które wolą publikować alarmistyczne artykuły o rzekomo niczym nieograniczonej ekspansji eksportowej Chin, a bardzo rzadko publikują rzeczowe dane mówiące o tym, że miejsca pracy ,znikają” także w Państwie Środka i przenoszone sąjuż od dobrych kilku lat do innych krajów rozwijających się, gdzie koszty pracy są najniższe. Chiny tracą też stopniowo swoją pozycję największego na świecie eksportera takich pracochłonnych towarów jak tekstylia i ubrania, wyroby skórzane i obuwie. Ich udział w światowym eksporcie tekstyliów i ubrań wynosił w 2010 roku 35\%, a krajów o niższych kosztach pracy $25 \%$, natomiast udziały te w 2014 roku wyniosły odpowiednio 32\% i 29\% (Foroohan, 2016; Slaughter, 2013). Podobny jest wzrost udziału krajów o niższych kosztach wytwarzania kosztem zmniejszenia udziału Chin w eksporcie innych grup towarów pracochłonnych, w tej liczbie także eksportowanych przez Wietnam, Malezję i Meksyk, tj. kraje, które przystąily do Partnerstwa Transpacyficznego.

\section{Martwe TPP - nowa szansa dla Chin?}

Niektórzy eksperci i politycy upatrywali w TPP ogromną szansę na przyśpieszenie handlu i wzrostu gospodarczego 12 krajów tego porozumienia oraz swoisty ratunek dla globalnej gospodarki. Inni z kolei wyrażali obawy, że TPP przyczyni się raczej do pogłębienia podziałów w Azji i nie wpłynie pozytywnie na pobudzenie handlu w całym tym regionie i gospodarce globalnej (Fenson, 2015; Goto, 2010). Bardzo trudno będzie zweryfikować obie te przeciwstawne opinie, gdyż w międzyczasie Partnerstwo Transpacyficzne stało się - podobnie jak TTIP - martwym porozumieniem handlowym. Nie zostało ono bowiem ratyfikowane przez parlamenty 12 uczestniczących w nim państw. Ponadto po wycofaniu się na początku lutego 2017 roku Stanów Zjednoczonych z tego porozumienia handlowego są bardzo niewielkie szanse na uratowanie TPP. Potwierdził to także premier Japonii Shinzo Abe, który już pod koniec stycznia 2017 roku stwierdził, że bez Stanów Zjednoczonych Partnerstwo Transpacyficzne nie będzie mogło funkcjonować (French, 2017; Olson, 2017). Z drugiej strony część z 11 pozostałych krajów, które podpisały to porozumienie handlowe zamierza teraz wynegocjować, bez udziału USA, nowy układ lub przyłączyć się w najbliższej przyszłości do partnerstwa gospodarczego, jakie chcą utworzyć w omawianym regionie Chiny.

Trudno przewidzieć czy w obliczu takiego „zagrożenia” ze strony Chin dojdzie w najbliższej przyszłości do zmiany decyzji podjętej na początku lutego 2017 roku przez prezydenta Donalda Trumpa. Przekonywał on jeszcze w trakcie swojej kampanii wyborczej, że TPP, NAFTA i inne podobne, wielostronne umowy o wolnym handlu są szkodliwe dla USA, gdyż powodują przenoszenie produkcji do krajów o znacznie niższych kosztach pracy. Należy raczej oczekiwać, że administracja prezydenta Donalda Trumpa będzie prowadzić protekcjonistyczną politykę, $\mathrm{w}$ ramach której cła oraz bariery pozataryfowe mogą się stać jednym z głównych instrumentów pomagających w wyrównywaniu 
szans Stanów Zjednoczonych w handlu międzynarodowym. Administracja ta znacząco więc ograniczy napływ na rynek amerykański nie tylko tanich towarów z Chin i innych krajów rozwijających się, lecz także towarów wysoko przetworzonych, takich jak samochody i elektronika użytkowa z Japonii, Niemiec i innych krajów gospodarczo wysoko rozwiniętych. Należy podkreślić, że Stany Zjednoczone mają od wielu lat ogromny deficyt w swoim bilansie handlowym, $w$ tym $z$ Chinami wynoszący 700 mld dol. a z Japonią 70 mld dol. (dane dla 2016 roku) (WTO, 2016). Można założyć, że wszystkie kraje, w handlu, z którymi Stany Zjednoczone mają deficyt, mogą mieć obecnie utrudniony dostęp do amerykańskiego rynku. A trudno im będzie znaleźć równie chłonny, jak amerykański, rynek zbytu na eksportowane przez nie towary przemysłowe, co negatywnie odbije się zarówno na dynamice, jak i wartości światowego handlu towarami i usługami, jak również na całej gospodarce globalnej.

Kwestią otwartą pozostaje ocena tego, kto najbardziej skorzysta na wycofaniu się Stanów Zjednoczonych z TPP i prawdopodobnie także z niektórych, innych wielostronnych porozumień handlowych? Wydaje się, że będą to przede wszystkim Chiny, które dążą do utworzenia konkurencyjnego wobec TPP Regionalnego Kompleksowego Partnerstwa Gospodarczego (Regional Comprehensive Economic Partnership - RCEP) obejmującego 10 państw członkowskich ASEAN (Brunei, Filipiny, Indonezja, Kambodża, Laos, Malezja, Mianmar, Singapur, Tajlandia i Wietnam) oraz sześć, z którymi ASEAN ma umowy o wolnym handlu (Australia, Chiny, Indie, Japonia, Korea Południowa i Nowa Zelandia). Ogółem mieszka w nich 3,4 mld osób, czyli 45\% ludności świata i przypada na nie $40 \%$ globalnego handlu. Wszystkie te ww. kraje wytwarzają około 30\% światowego PKB, co czyniłoby z RCEP zdecydowanie największy gospodarczo blok naszego globu (Woltersdorf, 2017; Niedziński, 2017). Rzecz jasna, wiodącą rolę w tym negocjowanym dopiero porozumieniu handlowym chciałyby odgrywać Chiny, które usiłują w tych negocjacjach przeforsować swoje ,reguły gry”, a raczej handlu, niekoniecznie korzystne dla wszystkich potencjalnych uczestników tego porozumienia handlowego. W odróżnieniu od TPP, Chiny jednak nie domagają się wprowadzenia przepisów, które chroniłyby własność intelektualną i zagraniczne inwestycje czy zapewniałyby międzynarodowe standardy pracy i działalność związków zawodowych. Być może niektóre z państw biorących udział w tych negocjacjach zgodzą się przyjąc chińskie „warunki” handlu i współpracy gospodarczej. Zbyt bowiem wczesne wycofanie się Stanów Zjednoczonych z TPP uważane jest za ogromny błąd. Decyzja ta bowiem pozbawiła administrację prezydenta Donald Trumpa możliwości wywierania nacisku na Chiny, także w innych sprawach niż kwestie gospodarcze. Można to tłumaczyć nie tylko brakiem doświadczenia nowego prezydenta USA i jego administracji, lecz także emocjonalnymi i często niezbyt przemyślanymi reakcjami na wydarzenia zachodzące w gospodarce światowej i polityce międzynarodowej. Większy wpływ na ten i inne błędy prezydenta Donalda Trumpa w stosunkach gospodarczych z resztą świata ma przyjęcie przez niego wzorców postępowania niektórych populistycznych jego poprzedników. Podejmowali oni decyzje odnośnie rozwoju handlu i polityki zagranicznej najczęściej przez pryzmat różnie zresztą rozumianego interesu narodowego Stanów Zjednoczonych. A takie decyzje prowadziły z reguły w niektórych okresach do polityki izolacjonizmu, która w obecnych realiach byłaby groźna i szkodliwa zarówno dla USA, jak i całego świata. Natomiast najbardziej odczuwalną w najbliższych latach dla Stanów Zjednoczonych stratą będzie 
osłabienie zaufania do tego supermocarstwa wśród jego sojuszników w Azji, z których pewna część może, chcąc nie chcąc, wpaść w orbitę wpływów Chin.

\section{Bibliografia}

Bajekal N. (2015), What will the Trans-Pacific Partnership do?, „Time” 12.10.

Bremmer I. (2017), Trump's New World order press nation over Globe, „Time” 23.01.

Cohn T. H. (2011), Global political economy, New York.

Davis A., Blass E. (2007), The future of workplace: views from the floor, „Futures”, nr 39.

Eberstadt N. (2016), Men without work: America's invisible crisis, West Conshohocken Templeton Press.

Fenson A. (2015), Can TPP rescue global economy?, „The Diplomat” 11.10.

Foroohan R. (2016), Is China stealing US jobs? Not exactly, „The Times” 11.04.

Foroohan R. (2016), After decades of consensus the value of global free trade is being contested by the left and the right, „Time” 11.04.

French E. (2017), The US, Japan, and trade: what Trump can learn from the 1990s, „The Diplomat” 7.02.

Goto S. (2010), Could the TPP actually divide Asia?, „The Diplomat” 22.10.

Habisch A., Popal P. (2013), Ethik und globaler Handel, „Aus Politik Und Zeitgeschichte” 30.12.

Kobrin S. J. (2005), Multinational Corporations, the Protest Movement, and the Future of Global Governance, w: Leviatans. Multinational Corporations and the new global history, red. A. D. Chandler, B. Mazlish, Cambridge.

Mildner S. (2009), Die Doha-Runde der WTO, ,SWP-Studie”, nr 1.

Vanishing jobs (2016), „The Economist” 20.09.

Niedziński B. (2017), W miejsce TPP może wejść Państwo Środka, „Dziennik Gazeta Prawna” 9.02.

Olson S. (2017), Evaluating 100 Days of Trump Trade Policy, „The Diplomat” 8.05.

Panda A. (2015), Trans-Pacific Partnership: prospects and challenges, „The Diplomat” 9.10.

Roberts D., Felton R. (2016), Clinton turns against the global economy as Americans Mount cost of trade Deal, „The Observer” 21.08.

Slaughter M. J. (2013), Free trade can lift US exports, „The Wall Street Journal” 24.01.

Strange S. (1996), The Retreat of the State, New York.

The Trans-Pacific Partnership: every silver lining has a cloud (2015), „The Economist” 10.10.

Woltersdorf A. (2017), Trans-Pacific Partnership: a sinking ship, „International Politics and Society” 12.02. WTO (2016), World Trade Statistical Review 2016, Geneva.

Blumenstein Rebecca: wywiad z Michaelem Fromanem pt. On a mission to free trade (2013), „The Wall Street Journal" 25.11.

Yough A. R. (2007), Negotiating with diminished expectations, w: The WTO after Hong Kong, red. D. Lee, R. Wilkinson, London-New York.

\section{The Retreat from Free Trade on the Example of Trans-Pacific Partnership}

\section{Summary}

In the recent times some rightist's political parties which have come to power in a number of Western states, seem to favour political arguments over the free trade advantages. The case of Trans-Pacific 
Partnership is the most illustrative as that regional free-trade agreement was aimed at "rebalancing" the economic cooperation within the Pacific region. It also was to create a trade bloc acting as a bulwark against China's hegemony in that region. The United States has promoted the seven years negotiation process which brought about in 2015 the creation of TPP. However that trade agreement was not ratified by the parliaments of the member countries till the beginning of 2017, and in February president Donald Trump withdrew the United States from the TPP. This created a room for the China's backed different proposition called the Regional Comprehensive Economic Partnership and highly weakened trust in the USA among its Asian allies.

Key words: free trade, protectionism, TPP, USA, China, Pacific Rim, RCEP 
